\title{
Apoptotic Cell-derived Extracellular Vesicles: Structure-Function Relationships
}

Lois R. Grant, Ivana Milic and Andrew Devitt.

School of Life and Health Sciences, Aston Research Centre for Healthy Ageing, Aston University, Birmingham, UK.

\section{Abbreviations}

AC - apoptotic cell

ACAMP - apoptotic cell-associated molecular pattern

ACdEV - apoptotic cell-derived extracellular vesicle

CX3CL1 - C-X3-C motif chemokine ligand 1

$\mathrm{BL}$ - Burkitt lymphoma

EV - extracellular vesicle

ECM - extracellular matrix

HMGB1 - high mobility group protein 1

ICAM-3 - intercellular adhesion molecule-3

LPC - lysophosphatidylcholine

MV - microvesicle

PMN - polymorphonuclear cell

PS - phosphatidylserine

S1P - sphingosine-1-phosphate 


\begin{abstract}
Apoptosis is an essential process for normal physiology and plays a key role in the resolution of inflammation. Clearance of apoptotic cells (ACs) involves complex signalling between phagocytic cells, $A C s$, and the extracellular vesicles (EVs) they produce. Here, we discuss apoptotic cell-derived extracellular vesicles (ACdEVs) and how their structure relates to their function in apoptotic cell clearance and the control of inflammation, focussing on the ACdEV proteome; we review the current knowledge, ongoing work and future directions for research in this field.
\end{abstract}

\title{
Introduction
}

Apoptosis plays a key role in physiology; it is the process by which unwanted cells are destroyed, which is central to development and immune regulation, in addition to normal cell turnover and homeostasis $[1,2]$. The process is genetically programmed and mediated by caspases which are involved in a proteolytic cascade ${ }^{[2]}$. Defects in apoptosis are implicated in many diseases including cancer ${ }^{[3,4]}$, inflammatory conditions and autoimmune disease ${ }^{[5-7]}$. Extracellular vesicles (EVs) are membraneenclosed structures secreted by cells, which are important mediators of intercellular communication in physiological and pathophysiological processes ${ }^{[8]}$. EVs are recognised as important mediators of inflammation and their immunomodulatory roles are significant in inflammatory diseases [9]. Apoptosis involves the disassembly of apoptotic cells into smaller fragments, including apoptotic cellderived extracellular vesicles (ACdEVs). ACdEVs are emerging as mediators of inflammation and promoters of apoptotic cell clearance ${ }^{[10,11]}$, although few of their specific functions have been identified ${ }^{[12-14]}$. Here, we discuss the significance of apoptotic cell-derived extracellular vesicles in apoptotic cell clearance and immune modulation, and the identification of key ACdEV molecules that mediate their functions. Many questions regarding ACdEVs remain to be answered and will be discussed here.

\section{Extracellular vesicles: complex mediators of intercellular communication}

The biogenesis of EVs incorporates components of the cell and, as such, EVs contain and signal via lipid mediators, nucleic acids and proteins ${ }^{[15-18]}$. Cells produce exosomes $(\sim 30-150 \mathrm{~nm})$ and microvesicles (MVs, $\sim 100-1000 \mathrm{~nm}$ ) which have distinct mechanisms of biogenesis ${ }^{[19]}$. Exosomes are generated through an endosomal pathway where multivesicular bodies, formed by the maturation of early endosomes into late endosomes, fuse with the plasma membrane and release their intraluminal vesicles ${ }^{[8]}$. MVs are produced by direct budding of plasma membrane ${ }^{[20]}$. It is likely that different stimuli change the rate of EV release and the composition of the EVs, as the phenotype of the stimulated cell changes. Apoptotic cells (ACs) produce apoptotic cell-derived extracellular vesicles (ACdEVs) of "greatly varying size" ${ }^{[1]}$, including apoptotic bodies (1-5 $\left.\mu \mathrm{m}\right)$ and smaller EVs which may or may not have the same biogenesis pathways as EVs produced by viable cells. Apoptotic bodies are produced by the process of membrane blebbing and other mechanisms of ACdEV biogenesis include formation of microtubule spikes, apoptopodia and beaded apoptopodia ${ }^{[1,22]}$. Release of exosomes by ACs remains to be confirmed in the literature. One key function of EVs may be to prevent degradation of their cargoes in the extracellular environment, and EVs can travel to cells and tissues at distant sites. EV-associated signals can be delivered to recipient cells via EV-cell surface interactions involving specific receptors, which facilitates targeting of specific cell types ${ }^{[8,18]}$. Otherwise, the content of EVs must be transferred into the recipient cell; internalisation of EVs can occur by membrane fusion, endocytosis, phagocytosis or macropinocytosis ${ }^{[23-27]}$ and the release of EV contents into the cytosol requires fusion of the EV membrane with the cell membrane or the membrane of endocytic compartments ${ }^{[8]}$. EVs and their contents may simply be destroyed in lysosomes after internalisation.

\section{Apoptosis and apoptotic cell clearance}


Apoptosis is the process of programmed cell death, first described in 1972 by Kerr et al. ${ }^{[1]}$, which is essential for normal cell turnover and homeostasis, development and tissue remodelling, as well as control of the immune system ${ }^{[2]}$. Efficient clearance of apoptotic cells prevents secondary necrosis and subsequent inflammatory responses ${ }^{[28]}$.. Apoptosis plays a central role in the resolution of inflammation, as immune cells that are no longer required undergo apoptosis and are cleared by phagocytes ${ }^{[29]}$. Resolution of inflammation involves the depletion of pro-inflammatory signals, inhibition of leukocyte migration and tissue infiltration, apoptosis and cell clearance. Apoptotic cell clearance is discussed in detail in a number of reviews ${ }^{[10,30-33]}$. Firstly, ACs release 'find me signals' which stimulate migration and recruitment of phagocytes to the site of cell death. The release of $A C$ 'find me' signals is regulated; for example, the release of ATP and UTP is mediated by pannexin 1 channels, which are opened on cleavage by activated caspases ${ }^{[34,35]}$. As well as the nucleotides ATP and UTP, other 'find me signals' released include chemokines such as CX3CL1 ${ }^{[14]}$, , and lipids such as lysophosphatidylcholine (LPC) ${ }^{[36]}$ and sphingosine-1-phosphate (S1P) ${ }^{[37]}$. Some signals released by ACs act to inhibit migration of phagocytes; for example, lactoferrin inhibits migration of granulocytes but not mononuclear phagocytes ${ }^{[38]}$. Once an $\mathrm{AC}$ has been located by a phagocyte, whether engulfment (efferocytosis) occurs is determined by the balance between 'don't eat me' and 'eat me' signals (apoptotic cell-associated molecular patterns - ACAMPs) presented on the cell surface ${ }^{\text {[39] }}$. Loss of membrane asymmetry and externalisation of PS is a hallmark of apoptosis, and PS is a key molecule for recognition of apoptotic cells which binds to various receptors on phagocytic cells ${ }^{[32,40]}$. Other 'eat me' signals on the surface of ACs recognised by scavenger receptors include the proteins, annexin 1 ${ }^{[41]}$, ICAM-3 ${ }^{[42]}$ and calreticulin ${ }^{[43,44]}$. Recognition and uptake of apoptotic cells also involves modification of the structure and function of 'don't eat me' signals such as CD31 and CD47 ${ }^{[44,45]}$.

\section{Apoptotic cell-derived EVs}

ACs disassemble into smaller fragments in the form of apoptotic bodies, smaller plasma membranederived microvesicles ${ }^{[22]}$, and AC potentially also release exosomes. The formation of ACdEVs plays an important role in apoptotic cell clearance, as they harbour AC 'find me' and 'eat me' signals and perhaps act as smaller and more easily engulfed cell fragments (Fig. 1). ACdEVs are therefore also central to control and resolution of inflammation. The surface proteome of EV likely determines EVcell interactions. This could be mediated by relatively simple physicochemical means (e.g. charge) and/or more specific and higher affinity ligand-receptor molecular interactions (e.g. through the recognition of proteins, lipids or carbohydrates), which mediate recognition, uptake and signalling ${ }^{[18]}$. Macrophages preferentially phagocytose ACdEVs with certain surface compositions, such as specific glycosylation patterns; a study by Bilyy et al. found that macrophages prioritised EVs presenting immature mannosidic glycoepitopes over those with desialylated glycolepitopes ${ }^{[46]}$. As well as surface molecules, ACdEVs will also signal via the transfer of proteins and nucleic acids into recipient cells. ACdEVs can contain pro- and anti-inflammatory mediators, but apoptosis and AC clearance is generally an non-inflammatory process. The anti-inflammatory functions of ACdEVs are important for prevention of autoimmune disease; for example, "apoptotic blebs" from lymphocytes downregulate MHC II expression on dendritic cells, but this process is impaired in systemic lupus erythematosus (SLE) patients ${ }^{[6]}$. Microvesicles from apoptotic neutrophils promote resolution of inflammation by suppression of the activity of T-helper cells ${ }^{[47]}$. Production of ACdEVs can create an amplification loop of cell death, promoting apoptosis in recipient cells and further release of ACdEVs ${ }^{[48]}$. There is a significant gap in our knowledge as the key molecules regulating these effects remain to be identified. The balance between inflammatory mediators changes over the course of apoptosis; therefore changes in the composition of ACdEVs over timeshould also be investigated. Tumour cell-derived ACdEVs are often anti-inflammatory, pro-resolution and create an onco-regenerative niche ${ }^{[49]}$. Additionally, ACdEVs can also play roles in promoting inflammation ${ }^{[7,50]}$, antigen presentation ${ }^{[17]}$ and 
infection - EVs can be hijacked to suppress immune responses or aid the spread of infection to neighbouring cells ${ }^{[51,52]}$.

\section{Identifying ACdEV structure-function relationships}

The molecular composition of EVs is a major focus for the field and this composition has led to an improved understanding of EVs and, in particular, how EV components (protein and non-protein based) may be used for the characterisation of different sub-types of EV. This is reviewed within the position statement from the International Society for Extracellular Vesicles ${ }^{[53]}$. Whilst many studies have identified roles for EVs in physiology or pathology, there is only a small number of studies that have characterised the functions of specific ACdEV-associated molecules. Current knowledge of the roles of lipids and lipid mediators has been reviewed previously ${ }^{[54]}$. In particular, PS is well characterised as an important marker of ACs for recognition by phagocytes [40]; it is also enriched on the surface of EVs, so it is likely to also play an important role in ACdEV recognition. In addition to lipid composition, the proteome of ACdEVs needs to be explored further: the surface proteome and what ACdEV-cell interactions occur, how specific molecules are recognised by recipient cells, and what molecules on ACdEVs act as 'find me' and/or 'eat me' signals. As well as those on the surface of ACdEVs, the molecules inside the vesicles, proteins and nucleic acids, which are transferred into recipient cells will contribute to their functions. Formation of ACdEVs is a highly regulated process ${ }^{[22]}$, as is packaging of EV cargoes, with differential sorting of cell components depending on the cell state and phenotype ${ }^{[55-58]}$. Changes in EV phenotype may occur over the course of apoptosis and there may be different waves of EV release. ACdEVs produced in early and late apoptosis have not been well characterised.

In 1999, Segundo et al. proposed that "apoptotic blebs" function as attractants to recruit macrophages to sites of cell death ${ }^{[12]}$; this study that found that a number of CD molecules (including CD11a, CD21, CD22 and CD54) are rapidly lost from the surface of apoptotic germinal centre B cells, partly via secretion of vesicles, and these "blebs" stimulated chemotaxis in human monocytes. Since then, CX3CL1 and ICAM-3 are the only ACdEV-associated proteins that have been studied and characterised in the context of apoptotic cell clearance ${ }^{[13,14]}$. CX3CL1, also known as fractalkine, is a chemokine and intercellular adhesion molecule expressed by various cell types; its receptor, CX3CR1 is expressed by mononuclear phagocytes. In a study on macrophage migration towards apoptotic lymphocytes, migration towards apoptotic Mutu Burkitt lymphoma (BL) cells was found to be dependent on the interaction of CX3CL1 and CX3CR1; CX3CL1 was shown to be rapidly lost from the surface of Mutu-BL cells following induction of apoptosis, in a $60 \mathrm{kDa}$ cleaved form which was found to be mostly "microparticle-associated" [14]. ICAM-3 is an intercellular adhesion molecule expressed by leukocytes and is involved in immune response signalling. ICAM-3 is also shed from apoptotic cells within ACdEVs termed "microparticles" [13]. ICAM-3 on the surface of these microparticles was shown to attract macrophages to sites of leukocyte cell death ${ }^{[13]}$. It is important to note that ICAM-3 is only expressed by leukocytes, so it is therefore not essential for clearance of all apoptotic cells and ACdEVs. However, it is possible that apoptosis-induced sub-molecular changes on ICAM-3 (e.g. altered glycosylation) may be occurring on other molecules such that there is functional conservation where ICAM-3 is absent.

A number of molecules that are on the surface of, or packaged into, ACdEVs have been identified, which are involved in controlling inflammation and apoptotic cell clearance, although the ACdEVassociated forms have not been functionally characterised. Annexins are commonly found on the surface of EVs ${ }^{[8]}$, including annexin 1 which is an anti-inflammatory, pro-resolving molecule ${ }^{[59]}$. Apoptosis induces the presentation of annexin 1 on the cell surface (co-localisation with PS) ${ }^{[41]}$, where it exhibits immunosuppressive functionality ${ }^{[59,60]}$. Annexin 1 promotes polymorphonuclear cell (PMN) apoptosis, recruitment of monocytes and clearance of apoptotic cells by macrophages. Annexin 1 has been shown to be present in EVs from healthy activated PMN and mediate their anti-inflammatory effects ${ }^{[61]}$. Annexin 1 on ACdEVs is therefore likely to be an important anti-inflammatory mediator. 
HMGB1 is an important nuclear protein, which is also released from immune cells to mediate immune responses such as chemotaxis and cytokine release ${ }^{[62]}$. HMGB1 can be pro- or anti-inflammatory depending on its posttranslational modifications; it contains 3 redox sensitive cysteines, and modification of these residues alters the activity of the protein [62]. Packaging of HMGB1 into EVs from healthy and apoptotic cells (including THP-1-derived macrophages, primary T-lymphocytes, Jurkat Tlymphocytes and HL-60 cells) has been demonstrated in a number of in vitro studies ${ }^{[63-66]}$; this has also been demonstrated in vivo in humans ${ }^{[67]}$. However, characterisation of the specific functions of this molecule in EV-mediated communication has not yet been performed. One study interestingly found that when comparing EV subpopulations from activated and apoptotic T-lymphocytes, HMGB1 was present almost exclusively in large ACdEVs ${ }^{[64]}$ and this highlights the importance of considering the significant vesicle heterogeneity in studies. There are many possible factors that may mediate the activity of ACdEVs. EVs can also contain active enzymes such as enzymes involved in ECM remodelling - proteases and glycosidases are present on the surface of "exosomes" [68-70]. EVs can also contain enzymes which can process other EV components to generate additional mediators ${ }^{[71]}$. Therefore, individual enzymatically-active EVs may be changing over time in structure, function and perhaps potency (e.g. they may become more immune-modulating over time following enzyme activity). How these activities might affect EV function remains to be determined but will require a pathway analysis of EV composition to assess, for example, if the substrates, enzymes and, if required, transporters (components of the EV surface proteome) of products are present and functional.

\section{Perspectives \& future directions}

EVs are recognised as significant mediators of intercellular communication involved in physiology and pathophysiology. While EVs produced by healthy and diseased cells have been studied over the last few decades, EVs derived from apoptotic cells have not been the main focus of research efforts. Proteomic analysis shows that the compositions of vesicles derived from apoptotic cells are distinct from those released by viable cells ${ }^{[64,72]}$, as does RNA profiling ${ }^{[73,74]}$, however the functional significance of these differences is poorly understood. ACdEVs have been shown to attract phagocytes to sites of cell death and promote apoptotic cell clearance. However, exactly how they signal in this context is not well characterised and their immunomodulatory functions need to be studied further. A very limited number of ACdEV-associated molecules have been characterised functionally. There are still some general issues in the field of extracellular vesicles. Methods for isolation and characterisation of EVs vary across the field, as do methods for defining subpopulations and use of nomenclature ${ }^{[53]}$. Currently exosomes, microvesicles and apoptotic bodies are distinguished by size, which is not entirely accurate, or by the presence of proteins that are exclusively found in exosomes. It may or may not be possible in the future to definitively separate and identify subpopulations of EVs. However, at present it is most appropriate to discuss ACdEVs as a whole. Previous studies on apoptosis and ACdEVs have focused on apoptotic bodies, but it is becoming apparent that the other populations ACdEVs also play important roles. Whether ACdEVs include exosomes has not been reported, and should be confirmed.

A number of important questions regarding the structure and functions of ACdEVs need to be addressed. Investigation of ACdEVs, identifying key molecules and their functions will provide valuable insight into how immune responses are modulated, how inflammation is controlled, how apoptotic cells are removed, and the processes behind diseases related to dysfunction in these systems. The impact of EVs on recipient cells is also of interest in the context of tissue environments. For example, cell death is known to modulate the tumour microenvironment to support tumour growth ${ }^{[75]}$ and ACdEVs will likely play a role in this. Such effects have been noted in other systems where EVs from stressed cells can promote greater resilience to stress in neighbouring cells ${ }^{[76,77]}$. ACdEVs are often considered to be simply smaller, more readily phagocytosed versions of apoptotic cells. However, packaging of lipid, protein and nucleic acid mediators into EVs can be specific as well as nonspecific, 
and these mediators are lost from the cell; ACdEVs may therefore not signal and be processed in exactly the same way as apoptotic cells. Current research aims to identify specific molecules present on the surface ACdEVs, how they are recognised by recipient cells and what their effects are. We must also consider the contribution of the whole proteome of these vesicles - what roles do proteins inside of ACdEVs play in mediating communication between apoptotic and other cells? When investigating the precise responses that ACdEVs induce in recipient cells it is important to look at what kinds of response-EVs are produced by recipient cells and how these amplify signals. Furthermore, it is plausible that different waves of ACdEVs are produced over the course of cell death, with different phenotypes and immunomodulatory functions; the changes in the population of ACdEVs over time should therefore be explored. The fact that EVs can carry active enzymes may also contribute to a changing population of ACdEVs. Another key question is what enzymes are present in ACdEVs and how does their enzymatic activity change EV structure and function over time? There is a great deal of complexity in this emerging field. 
A

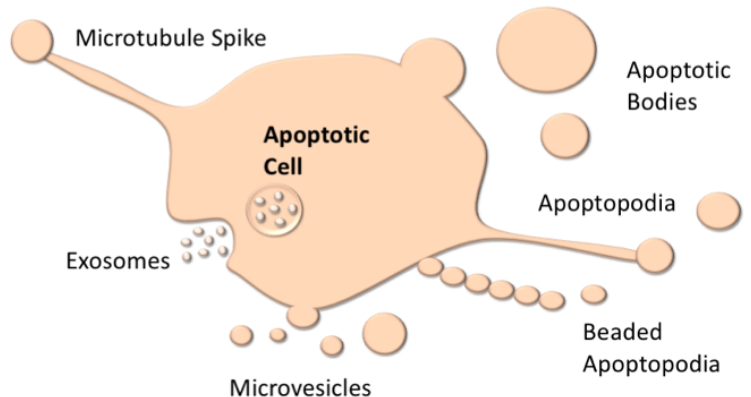

B

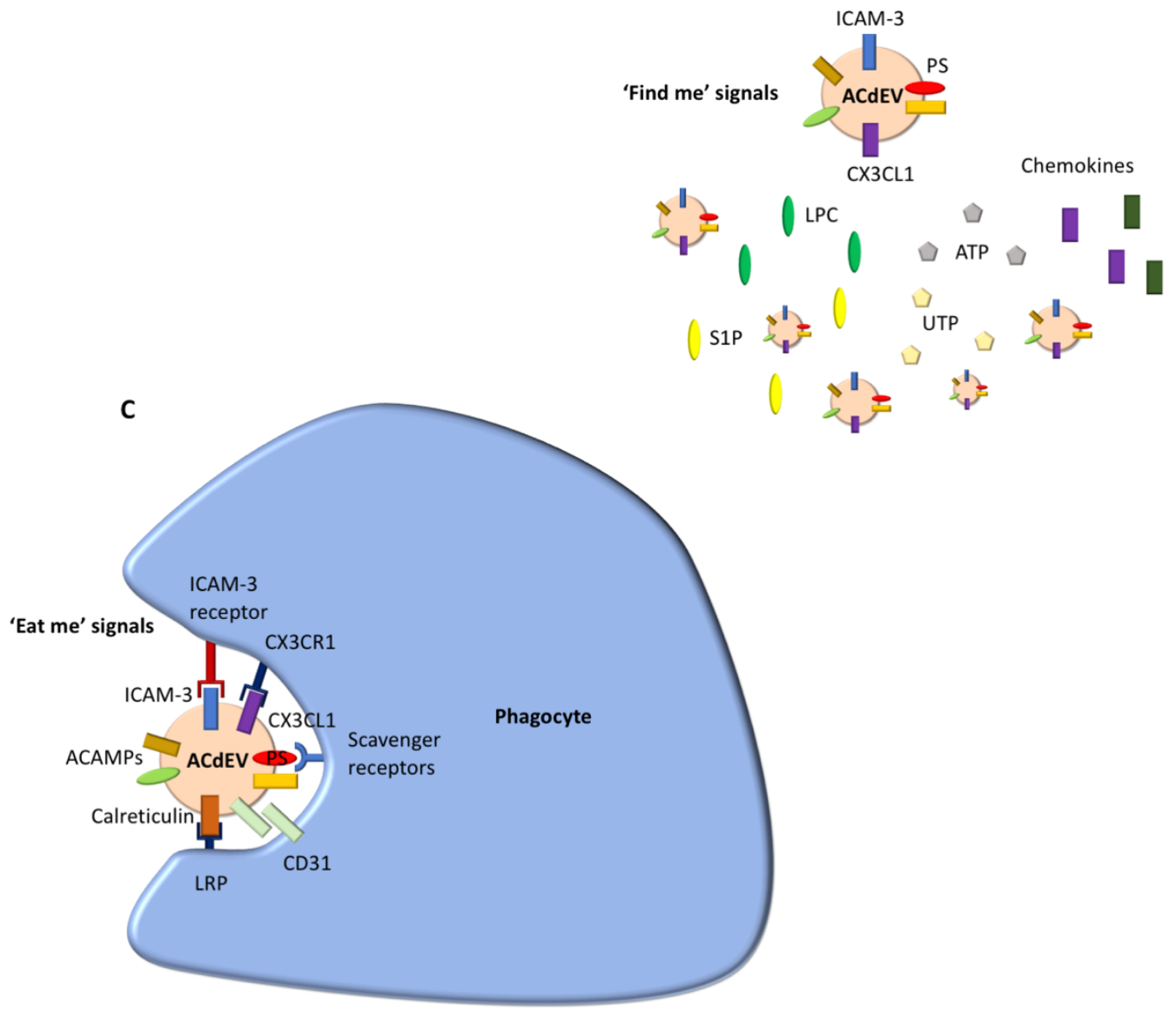

Figure 1. Apoptotic cell clearance in the resolution of inflammation

(1) Disassembly of apoptotic cells - ACs disassemble which generates ACdEVs of various sizes. (2) Location of ACs by phagocytes - 'Find me' signals including proteins such as CX3CL-1, nucleotides ATP and UTP, and lipids such as LPC and S1P attract phagocytes to sites of cell death (3) Recognition, tethering and efferocytosis apoptotic cells are recognised by various receptors on the surface of phagocytes. 'Don't eat me' signals are altered, silenced and/or overwhelmed by 'eat me' signals including PS, annexin 1, ICAM-3 and calreticulin, and apoptotic cells are ultimately phagocytosed. ACdEVs are likely to also be recognised and engulfed via these mechanisms. (LRP - LDL-receptor-related protein). 


\section{References}

[1] Kerr JFR, Wyllie AH, Currie AR. (1972) Apoptosis: A Basic Biological Phenomenon with Wideranging Implications in Tissue Kinetics. Br. J. Cancer [Internet]. 26, 239-257. Available from: http://www.nature.com/articles/bjc197233

[2] Elmore S. (2007) Apoptosis: a review of programmed cell death. Toxicol. Pathol. [Internet]. 35, 495-516. Available from: http://www.ncbi.nlm.nih.gov/pubmed/17562483

[3] Kerr JFR, Winterford CM, Harmon B V. (1994) Apoptosis. Its significance in cancer and cancer Therapy. Cancer [Internet]. 73, 2013-2026. Available from:

http://doi.wiley.com/10.1002/1097-0142\%2819940415\%2973\%3A8\%3C2013\%3A\%3AAIDCNCR2820730802\%3E3.0.CO\%3B2-J

[4] Fernald K, Kurokawa M. (2013) Evading apoptosis in cancer. Trends Cell Biol. [Internet]. 23, 620-633. Available from:

https://www.sciencedirect.com/science/article/pii/S0962892413001177

[5] Mahoney JA, Rosen A. (2005) Apoptosis and autoimmunity. Curr. Opin. Immunol. [Internet]. 17, 583-588. Available from: https://www.sciencedirect.com/science/article/pii/S095279150500155X\#bib41

[6] Fehr E-M, Spoerl S, Heyder P, Herrmann M, Bekeredjian-Ding I, Blank N, et al. (2013) Apoptotic-cell-derived membrane vesicles induce an alternative maturation of human dendritic cells which is disturbed in SLE. J. Autoimmun. [Internet]. 40, 86-95. Available from: https://www.sciencedirect.com/science/article/pii/S0896841112001230

[7] Niessen A, Heyder P, Krienke S, Blank N, Tykocinski L-O, Lorenz H-M, et al. (2015) Apoptoticcell-derived membrane microparticles and IFN- $\alpha$ induce an inflammatory immune response. J. Cell Sci. [Internet]. 128, 2443-53. Available from: http://www.ncbi.nlm.nih.gov/pubmed/26034070

[8] Colombo M, Raposo G, Théry C. (2014) Biogenesis, Secretion, and Intercellular Interactions of Exosomes and Other Extracellular Vesicles. Annu. Rev. Cell Dev. Biol. [Internet]. 30, 255-289. Available from: http://www.annualreviews.org/doi/10.1146/annurev-cellbio-101512-122326

[9] Buzas El, György B, Nagy G, Falus A, Gay S. (2014) Emerging role of extracellular vesicles in inflammatory diseases. Nat. Rev. Rheumatol. [Internet]. 10, 356-364. Available from: http://dx.doi.org/10.1038/nrrheum.2014.19

[10] Poon IKH, Lucas CD, Rossi AG, Ravichandran KS. (2014) Apoptotic cell clearance: basic biology and therapeutic potential. Nat. Rev. Immunol. [Internet]. 14, 166-180. Available from: http://www.nature.com/articles/nri3607

[11] Caruso S, Poon IKH. (2018) Apoptotic Cell-Derived Extracellular Vesicles: More Than Just Debris. Front. Immunol. [Internet]. 9, 1486. Available from:

http://www.ncbi.nlm.nih.gov/pubmed/30002658

[12] Segundo C, Medina F, Rodríguez C, Martínez-Palencia R, Leyva-Cobián F, Brieva JA. (1999) Surface Molecule Loss and Bleb Formation by Human Germinal Center B Cells Undergoing Apoptosis: Role of Apoptotic Blebs in Monocyte Chemotaxis. Blood. 94.

[13] Torr EE, Gardner DH, Thomas L, Goodall DM, Bielemeier A, Willetts R, et al. (2012) Apoptotic cell-derived ICAM-3 promotes both macrophage chemoattraction to and tethering of apoptotic cells. Cell Death Differ. [Internet]. 19, 671-679. Available from: http://www.nature.com/articles/cdd2011167

[14] Truman LA, Ford CA, Pasikowska M, Pound JD, Wilkinson SJ, Dumitriu IE, et al. (2008) CX3CL1/fractalkine is released from apoptotic lymphocytes to stimulate macrophage chemotaxis. Blood [Internet]. 112, 5026-36. Available from: http://www.ncbi.nlm.nih.gov/pubmed/18799722

[15] Sagini K, Costanzi E, Emiliani C, Buratta S, Urbanelli L, Sagini K, et al. (2018) Extracellular Vesicles as Conveyors of Membrane-Derived Bioactive Lipids in Immune System. Int. J. Mol. 
Sci. [Internet]. 19, 1227. Available from: http://www.mdpi.com/1422-0067/19/4/1227

[16] Valadi H, Ekström K, Bossios A, Sjöstrand M, Lee JJ, Lötvall JO. (2007) Exosome-mediated transfer of mRNAs and microRNAs is a novel mechanism of genetic exchange between cells. Nat. Cell Biol. [Internet]. 9, 654-659. Available from: http://www.nature.com/articles/ncb1596

[17] Raposo G, Nijman HW, Stoorvogel W, Liejendekker R, Harding C V, Melief CJ, et al. (1996) B lymphocytes secrete antigen-presenting vesicles. J. Exp. Med. [Internet]. 183, 1161-72. Available from: http://www.ncbi.nlm.nih.gov/pubmed/8642258

[18] Buzás El, Tóth EÁ, Sódar BW, Szabó-Taylor KÉ. (2018) Molecular interactions at the surface of extracellular vesicles. Semin. Immunopathol. [Internet]. 40, 453-464. Available from: http://link.springer.com/10.1007/s00281-018-0682-0

[19] Akers JC, Gonda D, Kim R, Carter BS, Chen CC. (2013) Biogenesis of extracellular vesicles (EV): exosomes, microvesicles, retrovirus-like vesicles, and apoptotic bodies. J. Neurooncol. [Internet]. 113, 1-11. Available from: http://www.ncbi.nlm.nih.gov/pubmed/23456661

[20] Heijnen HFG, Schiel AE, Fijnheer R, Geuze HJ, Sixma JJ. (1999) Activated Platelets Release Two Types of Membrane Vesicles: Microvesicles by Surface Shedding and Exosomes Derived From Exocytosis of Multivesicular Bodies and -Granules. Blood. 94.

[21] Atkin-Smith GK, Tixeira R, Paone S, Mathivanan S, Collins C, Liem M, et al. (2015) A novel mechanism of generating extracellular vesicles during apoptosis via a beads-on-a-string membrane structure. Nat. Commun. [Internet]. 6, 7439. Available from: http://www.nature.com/articles/ncomms8439

[22] Atkin-Smith GK, Poon IKH. (2017) Disassembly of the Dying: Mechanisms and Functions. Trends Cell Biol. [Internet]. 27, 151-162. Available from: https://www.sciencedirect.com/science/article/pii/S0962892416301295?via\%3Dihub

[23] Montecalvo A, Larregina AT, Shufesky WJ, Stolz DB, Sullivan MLG, Karlsson JM, et al. (2012) Mechanism of transfer of functional microRNAs between mouse dendritic cells via exosomes. Blood [Internet]. 119, 756-766. Available from: http://www.bloodjournal.org/content/119/3/756.long?sso-checked=true

[24] Svensson KJ, Christianson HC, Wittrup A, Bourseau-Guilmain E, Lindqvist E, Svensson LM, et al. (2013) Exosome uptake depends on ERK1/2-heat shock protein 27 signaling and lipid Raftmediated endocytosis negatively regulated by caveolin-1. J. Biol. Chem. [Internet]. 288, 17713-24. Available from: http://www.ncbi.nlm.nih.gov/pubmed/23653359

[25] Mulcahy LA, Pink RC, Carter DRF. (2014) Routes and mechanisms of extracellular vesicle uptake. J. Extracell. Vesicles. 3, 1-14.

[26] Feng D, Zhao W-L, Ye Y-Y, Bai X-C, Liu R-Q, Chang L-F, et al. (2010) Cellular Internalization of Exosomes Occurs Through Phagocytosis. Traffic [Internet]. 11, 675-687. Available from: http://doi.wiley.com/10.1111/j.1600-0854.2010.01041.x

[27] Fitzner D, Schnaars M, van Rossum D, Krishnamoorthy G, Dibaj P, Bakhti M, et al. (2011) Selective transfer of exosomes from oligodendrocytes to microglia by macropinocytosis. J. Cell Sci. [Internet]. 124, 447-58. Available from: http://www.ncbi.nlm.nih.gov/pubmed/21242314

[28] Sachet M, Liang YY, Oehler R. (2017) The immune response to secondary necrotic cells. Apoptosis [Internet]. 22, 1189-1204. Available from: http://www.ncbi.nlm.nih.gov/pubmed/28861714

[29] Ortega-Gómez A, Perretti M, Soehnlein O. (2013) Resolution of inflammation: an integrated view. EMBO Mol. Med. [Internet]. 5, 661-74. Available from:

http://www.ncbi.nlm.nih.gov/pubmed/23592557

[30] Gregory CD, Devitt A. (2004) The macrophage and the apoptotic cell: an innate immune interaction viewed simplistically? Immunology [Internet]. 113, 1-14. Available from: http://www.ncbi.nlm.nih.gov/pubmed/15312130

[31] Hawkins LA, Devitt A. (2013) Current Understanding of the Mechanisms for Clearance of 
Apoptotic Cells-A Fine Balance. J. Cell Death [Internet]. 6, JCD.S11037. Available from: http://journals.sagepub.com/doi/10.4137/JCD.S11037

[32] Penberthy KK, Ravichandran KS. (2016) Apoptotic cell recognition receptors and scavenger receptors. Immunol. Rev. [Internet]. 269, 44-59. Available from:

http://www.ncbi.nlm.nih.gov/pubmed/26683144

[33] Gheibi Hayat SM, Bianconi V, Pirro M, Sahebkar A. (2018) Efferocytosis: molecular mechanisms and pathophysiological perspectives. Immunol. Cell Biol. [Internet]. Available from: http://doi.wiley.com/10.1111/imcb.12206

[34] Elliott MR, Chekeni FB, Trampont PC, Lazarowski ER, Kadl A, Walk SF, et al. (2009) Nucleotides released by apoptotic cells act as a find-me signal to promote phagocytic clearance. Nature [Internet]. 461, 282-286. Available from:

http://www.nature.com/doifinder/10.1038/nature08296

[35] Chekeni FB, Elliott MR, Sandilos JK, Walk SF, Kinchen JM, Lazarowski ER, et al. (2010) Pannexin 1 channels mediate 'find-me' signal release and membrane permeability during apoptosis. Nature [Internet]. 467, 863-867. Available from:

http://www.nature.com/articles/nature09413

[36] Lauber K, Bohn E, Kröber SM, Xiao Y, Blumenthal SG, Lindemann RK, et al. (2003) Apoptotic Cells Induce Migration of Phagocytes via Caspase-3-Mediated Release of a Lipid Attraction Signal. Cell [Internet]. 113, 717-730. Available from:

https://www.sciencedirect.com/science/article/pii/S0092867403004227?via\%3Dihub

[37] Gude DR, Alvarez SE, Paugh SW, Mitra P, Yu J, Griffiths R, et al. (2008) Apoptosis induces expression of sphingosine kinase 1 to release sphingosine-1-phosphate as a "come-and-getme" signal. FASEB J. [Internet]. 22, 2629-38. Available from:

http://www.ncbi.nlm.nih.gov/pubmed/18362204

[38] Bournazou I, Pound JD, Duffin R, Bournazos S, Melville LA, Brown SB, et al. (2009) Apoptotic human cells inhibit migration of granulocytes via release of lactoferrin. J. Clin. Invest. [Internet]. 119, 20-32. Available from: http://www.ncbi.nlm.nih.gov/pubmed/19033648

[39] Grimsley C, Ravichandran KS. (2003) Cues for apoptotic cell engulfment: eat-me, don't eat-me and come-get-me signals. Trends Cell Biol. [Internet]. 13, 648-656. Available from: https://www.sciencedirect.com/science/article/pii/S0962892403002460?via\%3Dihub

[40] Fadok VA, de Cathelineau A A de, Daleke DL, Henson PM, Bratton DL. (2001) Loss of phospholipid asymmetry and surface exposure of phosphatidylserine is required for phagocytosis of apoptotic cells by macrophages and fibroblasts. J. Biol. Chem. [Internet]. 276, 1071-7. Available from: http://www.ncbi.nlm.nih.gov/pubmed/10986279

[41] Arur S, Uche UE, Rezaul K, Fong M, Scranton V, Cowan AE, et al. (2003) Annexin I Is an Endogenous Ligand that Mediates Apoptotic Cell Engulfment. Dev. Cell [Internet]. 4, 587-598. Available from:

https://www.sciencedirect.com/science/article/pii/S153458070300090X?via\%3Dihub

[42] Moffatt OD, Devitt A, Bell ED, Simmons DL, Gregory CD. (1999) Macrophage recognition of ICAM-3 on apoptotic leukocytes. J. Immunol. [Internet]. 162, 6800-10. Available from: http://www.ncbi.nlm.nih.gov/pubmed/10352301

[43] Ogden CA, deCathelineau A, Hoffmann PR, Bratton D, Ghebrehiwet B, Fadok VA, et al. (2001) C1q and mannose binding lectin engagement of cell surface calreticulin and CD91 initiates macropinocytosis and uptake of apoptotic cells. J. Exp. Med. [Internet]. 194, 781-95. Available from: http://www.ncbi.nlm.nih.gov/pubmed/11560994

[44] Gardai SJ, McPhillips KA, Frasch SC, Janssen WJ, Starefeldt A, Murphy-Ullrich JE, et al. (2005) Cell-Surface Calreticulin Initiates Clearance of Viable or Apoptotic Cells through transActivation of LRP on the Phagocyte. Cell [Internet]. 123, 321-334. Available from: https://www.sciencedirect.com/science/article/pii/S009286740500869X?via\%3Dihub

[45] Brown S, Heinisch I, Ross E, Shaw K, Buckley CD, Savill J. (2002) Apoptosis disables CD31mediated cell detachment from phagocytes promoting binding and engulfment. Nature 
[Internet]. 418, 200-203. Available from: http://www.nature.com/articles/nature00811

[46] Bilyy RO, Shkandina T, Tomin A, Muñoz LE, Franz S, Antonyuk V, et al. (2012) Macrophages discriminate glycosylation patterns of apoptotic cell-derived microparticles. J. Biol. Chem. [Internet]. 287, 496-503. Available from: http://www.ncbi.nlm.nih.gov/pubmed/22074924

[47] Shen G, Krienke S, Schiller P, Nießen A, Neu S, Eckstein V, et al. (2017) Microvesicles released by apoptotic human neutrophils suppress proliferation and IL-2/IL-2 receptor expression of resting T helper cells. Eur. J. Immunol. [Internet]. 47, 900-910. Available from: http://doi.wiley.com/10.1002/eji.201546203

[48] Distler JHW, Huber LC, Hueber AJ, Reich CF, Gay S, Distler O, et al. (2005) The release of microparticles by apoptotic cells and their effects on macrophages. Apoptosis [Internet]. 10, 731-741. Available from: http://link.springer.com/10.1007/s10495-005-2941-5

[49] Gregory CD, Dransfield I. (2018) Apoptotic Tumor Cell-Derived Extracellular Vesicles as Important Regulators of the Onco-Regenerative Niche. Front. Immunol. [Internet]. 9, 1111. Available from: https://www.frontiersin.org/article/10.3389/fimmu.2018.01111/full

[50] Schiller M, Parcina M, Heyder P, Foermer S, Ostrop J, Leo A, et al. (2012) Induction of type I IFN is a physiological immune reaction to apoptotic cell-derived membrane microparticles. J. Immunol. [Internet]. 189, 1747-56. Available from:

http://www.ncbi.nlm.nih.gov/pubmed/22786771

[51] Frleta D, Ochoa CE, Kramer HB, Khan SA, Stacey AR, Borrow P, et al. (2012) HIV-1 infectioninduced apoptotic microparticles inhibit human DCs via CD44. J. Clin. Invest. [Internet]. 122, 4685-97. Available from: http://www.ncbi.nlm.nih.gov/pubmed/23160198

[52] Bello-Morales R, Praena B, de la Nuez C, Rejas MT, Guerra M, Galán-Ganga M, et al. (2018) Role of Microvesicles in the Spread of Herpes Simplex Virus 1 in Oligodendrocytic Cells. J. Virol. [Internet]. 92. Available from: http://www.ncbi.nlm.nih.gov/pubmed/29514899

[53] Théry C, Witwer KW, Aikawa E, Alcaraz MJ, Anderson JD, Andriantsitohaina R, et al. (2018) Minimal information for studies of extracellular vesicles 2018 (MISEV2018): a position statement of the International Society for Extracellular Vesicles and update of the MISEV2014 guidelines. J. Extracell. Vesicles [Internet]. 7, 1535750. Available from: https://www.tandfonline.com/doi/full/10.1080/20013078.2018.1535750

[54] Devitt A, Griffiths HR, Milic I. (2018) Communicating with the dead: lipids, lipid mediators and extracellular vesicles. Biochem. Soc. Trans. [Internet]. , BST20160477. Available from: https://doi.org/10.1042/BST20160477

[55] Salzer U, Hinterdorfer P, Hunger U, Borken C, Prohaska R. (2002) Ca++-dependent vesicle release from erythrocytes involves stomatin-specific lipid rafts, synexin (annexin VII), and sorcin. Blood. 99, 2569-2577.

[56] Gassart A de, Géminard C, Février B, Raposo G, Vidal M. (2003) Lipid raft-associated protein sorting in exosomes. Blood. 102, 4336-4344.

[57] Squadrito ML, Baer C, Burdet F, Maderna C, Gilfillan GD, Lyle R, et al. (2014) Endogenous RNAs Modulate MicroRNA Sorting to Exosomes and Transfer to Acceptor Cells. Cell Rep. [Internet]. 8, 1432-1446. Available from: https://www.sciencedirect.com/science/article/pii/S2211124714006196

[58] Cha DJ, Franklin JL, Dou Y, Liu Q, Higginbotham JN, Demory Beckler M, et al. (2015) KRASdependent sorting of miRNA to exosomes. Elife [Internet]. 4. Available from: https://elifesciences.org/articles/07197

[59] Sugimoto MA, Vago JP, Teixeira MM, Sousa LP. (2016) Annexin A1 and the Resolution of Inflammation: Modulation of Neutrophil Recruitment, Apoptosis, and Clearance. J. Immunol. Res. [Internet]. 2016, 1-13. Available from: http://www.hindawi.com/journals/jir/2016/8239258/

[60] Weyd H, Abeler-Dörner L, Linke B, Mahr A, Jahndel V, Pfrang S, et al. (2013) Annexin A1 on the Surface of Early Apoptotic Cells Suppresses CD8+ T Cell Immunity. PLoS One [Internet]. 8, e62449. Available from: https://dx.plos.org/10.1371/journal.pone.0062449 
[61] Dalli J, Norling L V, Renshaw D, Cooper D, Leung K-Y, Perretti M. (2008) Annexin 1 mediates the rapid anti-inflammatory effects of neutrophil-derived microparticles. Blood [Internet]. 112, 2512-9. Available from: http://www.ncbi.nlm.nih.gov/pubmed/18594025

[62] Yang H, Antoine DJ, Andersson U, Tracey KJ. (2013) The many faces of HMGB1: molecular structure-functional activity in inflammation, apoptosis, and chemotaxis. J. Leukoc. Biol. [Internet]. 93, 865-873. Available from: http://doi.wiley.com/10.1189/jlb.1212662

[63] Chen Y, Li G, Liu Y, Werth VP, Williams KJ, Liu M-L. (2016) Translocation of Endogenous Danger Signal HMGB1 From Nucleus to Membrane Microvesicles in Macrophages. J. Cell. Physiol. [Internet]. 231, 2319-2326. Available from: http://doi.wiley.com/10.1002/jcp.25352

[64] Tucher C, Bode K, Schiller P, Claßen L, Birr C, Souto-Carneiro MM, et al. (2018) Extracellular Vesicle Subtypes Released From Activated or Apoptotic T-Lymphocytes Carry a Specific and Stimulus-Dependent Protein Cargo. Front. Immunol. [Internet]. 9, 534. Available from: http://journal.frontiersin.org/article/10.3389/fimmu.2018.00534/full

[65] Schiller M, Heyder P, Ziegler S, Niessen A, Claßen L, Lauffer A, et al. (2013) During apoptosis HMGB1 is translocated into apoptotic cell-derived membraneous vesicles. Autoimmunity [Internet]. 46, 342-346. Available from: http://www.tandfonline.com/doi/full/10.3109/08916934.2012.750302

[66] Spencer DM, Mobarrez F, Wallén H, Pisetsky DS. (2014) The Expression of HMGB1 on Microparticles from Jurkat and HL-60 Cells Undergoing Apoptosis in vitro. Scand. J. Immunol. [Internet]. 80, 101-110. Available from: http://doi.wiley.com/10.1111/sji.12191

[67] Pisetsky DS. (2014) The expression of HMGB1 on microparticles released during cell activation and cell death in vitro and in vivo. Mol. Med. [Internet]. 20, 158-63. Available from: http://www.ncbi.nlm.nih.gov/pubmed/24618884

[68] Sumida M, Hane M, Yabe U, Shimoda Y, Pearce OMT, Kiso M, et al. (2015) Rapid Trimming of Cell Surface Polysialic Acid (PolySia) by Exovesicular Sialidase Triggers Release of Preexisting Surface Neurotrophin. J. Biol. Chem. [Internet]. 290, 13202-14. Available from: http://www.ncbi.nlm.nih.gov/pubmed/25750127

[69] Hakulinen J, Sankkila L, Sugiyama N, Lehti K, Keski-Oja J. (2008) Secretion of active membrane type 1 matrix metalloproteinase (MMP-14) into extracellular space in microvesicular exosomes. J. Cell. Biochem. [Internet]. 105, 1211-1218. Available from: http://doi.wiley.com/10.1002/jcb.21923

[70] Sanderson RD, Bandari SK, Vlodavsky I. (2017) Proteases and glycosidases on the surface of exosomes: Newly discovered mechanisms for extracellular remodeling. Matrix Biol. [Internet]. Available from: https://www.sciencedirect.com/science/article/pii/S0945053X17303116

[71] Esser J, Gehrmann U, D'Alexandri FL, Hidalgo-Estévez AM, Wheelock CE, Scheynius A, et al. (2010) Exosomes from human macrophages and dendritic cells contain enzymes for leukotriene biosynthesis and promote granulocyte migration. J. Allergy Clin. Immunol. [Internet]. 126, 1032-1040.e4. Available from: https://www.sciencedirect.com/science/article/pii/S0091674910010419?via\%3Dihub

[72] Théry C, Boussac M, Véron P, Ricciardi-Castagnoli P, Raposo G, Garin J, et al. (2001) Proteomic analysis of dendritic cell-derived exosomes: a secreted subcellular compartment distinct from apoptotic vesicles. J. Immunol. [Internet]. 166, 7309-18. Available from: http://www.ncbi.nlm.nih.gov/pubmed/11390481

[73] Crescitelli R, Lässer C, Szabó TG, Kittel A, Eldh M, Dianzani I, et al. (2013) Distinct RNA profiles in subpopulations of extracellular vesicles: apoptotic bodies, microvesicles and exosomes. J. Extracell. Vesicles [Internet]. 2, 20677. Available from: https://www.tandfonline.com/doi/full/10.3402/jev.v2i0.20677

[74] Than UTT, Guanzon D, Broadbent JA, Leavesley DI, Salomon C, Parker TJ. (2018) Differential Expression of Keratinocyte-Derived Extracellular Vesicle Mirnas Discriminate Exosomes From Apoptotic Bodies and Microvesicles. Front. Endocrinol. (Lausanne). [Internet]. 9, 535. 
Available from: https://www.frontiersin.org/article/10.3389/fendo.2018.00535/full

[75] Ford CA, Petrova S, Pound JD, Voss JJLP, Melville L, Paterson M, et al. (2015) Oncogenic properties of apoptotic tumor cells in aggressive B cell lymphoma. Curr. Biol. [Internet]. 25, 577-88. Available from: http://www.ncbi.nlm.nih.gov/pubmed/25702581

[76] Bewicke-Copley F, Mulcahy LA, Jacobs LA, Samuel P, Akbar N, Pink RC, et al. (2017) Extracellular vesicles released following heat stress induce bystander effect in unstressed populations. J. Extracell. Vesicles [Internet]. 6, 1340746. Available from: https://www.tandfonline.com/doi/full/10.1080/20013078.2017.1340746

[77] Samuel P, Mulcahy LA, Furlong F, McCarthy HO, Brooks SA, Fabbri M, et al. (2018) Cisplatin induces the release of extracellular vesicles from ovarian cancer cells that can induce invasiveness and drug resistance in bystander cells. Philos. Trans. R. Soc. B Biol. Sci. [Internet]. 373, 20170065. Available from:

http://rstb.royalsocietypublishing.org/lookup/doi/10.1098/rstb.2017.0065 